\title{
Escutar a escrita: por uma teoria literária ameríndia ${ }^{1}$
}

Marília Librandi-Rocha

Universidade de Stanford

Resumo: Este texto estabelece pontes entre a teoria da literatura e a etnoantropologia contemporânea, e propõe repensar a noção de ficção a partir de conceitos do mundo ameríndio. Ilustra a discussão uma análise da "liçāo de escritura", de Tristes trópicos, relida não como farsa, mas como forç̧a e arte. Palavras-chave: Claude Lévi-Strauss, Nambikwaras, Eduardo Viveiros de Castro.

Prova de que também meios insuficientes e mesmo infantis podem servir para a salvação. Kafka. "O Silêncio das Sereias".

\begin{abstract}
Este texto procura ler um certo silêncio, dizê-lo em palavras e talvez, principalmente, engendrar a possibilidade de ouvi-lo. Como indaga Jean-Luc Nancy,
\end{abstract}

1. Esse texto é o resultado e a versão revista em português de duas palestras: "Mimesis and Auditivity", apresentada na Universidade de Queensland, Austrália, em novembro de 2011, por ocasião de um seminário dedicado à teoria da mimesis de Luiz Costa Lima; e "Thinking about Literature as a Native", palestra apresentada na Universidade de Stanford em fevereiro de 2012, como parte da série "How I think about Literature". 
em À L'écoute, seria o pensamento ocidental capaz de ouvir ou, como ele propõe, seria preciso inventar uma ontologia da escuta baseada na relação reverberante de nosso corpo com seu entorno? Direção semelhante segue Michelle Boulous Walker em seu livro Philosophy and the maternal body: reading silence. Como diz o título de seu primeiro capítulo, "Speaking Silence", o silêncio que eu gostaria de ler (e de ouvir) é precisamente um silêncio falante, e foi produzido por um chefe indígena Nambikwara.

Em 1938, esse índio desenhou algumas linhas em um pedaço de papel diante do antropólogo Claude Lévi-Strauss. Essas linhas reproduziam o gesto da escrita sem, no entanto, gerarem um texto: eram linhas tortas e sinuosas rabiscadas no papel. Como se sabe, Lévi-Strauss interpretou-as magnificamente em seu capítulo, "Lição de Escritura", em Tristes trópicos, publicado em 1955. Doze anos depois, Jacques Derrida contrainterpretou violentamente a interpretação de Lévi-Strauss em De la grammatologie, publicado em 1967. Tão violentamente, que, em sua carta-resposta, Lévi-Strauss diz que Derrida o contestara com "a delicadeza de um urso". ${ }^{2}$ No entanto, apesar da grande diferença entre eles, ambos os autores interpretaram essas linhas para criticar sua cultura de origem. Usando distintas estratégias, o objetivo era criticar o domínio colonial europeu, no caso de Lévi-Strauss, e a metafísica europeia dominante, no caso de Derrida. Mas o que acontece com o ponto de vista Nambikwara sobre sua própria escrita? O que essa lição nos diz sob o ponto de vista indígena? De certo modo, é possivel dizer que nem Lévi-Strauss nem Derrida leram o traço do índio; nenhum dos dois leu o silêncio desses traços como um contratexto em relação ao texto ocidental, e aquelas linhas no papel continuam a ser um enigma, uma espécie de hieróglifo Nambikwara virtual, já que essa escrita não foi preservada como os outros objetos indígenas levados por Lévi-Strauss para o Musée de L'Homme em Paris. Como não há vestígio material desses traços, apenas podemos saber deles a partir do modo como LéviStrauss os analisa em seu ensaio, do modo como Derrida o contradiz, e do modo como continuam a reverberar como questão em aberto.

Sabemos que o estruturalismo está ligado ao encontro de Lévi-Strauss com os Nambikwaras, sua mais longa experiência de campo, de junho a setembro

2. Antes da publicação do livro, Derrida publicara trechos de sua análise na revista Cabiers pour l'Analyse em 1966. É para essa revista que LéviStrauss envia sua carta-resposta. Cf. LEVI-STRAUSs. http:// cahiers.kingston.ac.uk/vol08/cpa8.5.levi-strauss.html. 
de 1938, que lhe fornece o fundamento teórico de seu primeiro livro, As estruturas elementares do parentesco, além de artigos anteriores, e de sua tese de 1948, La vie familiale et sociale des indiens Nambikwara. ${ }^{3}$ Sabemos também que o pósestruturalismo derridiano vai se estabelecer a partir de uma revisão radical desse mesmo encontro entre o antropólogo e o indígena Nambikwara. A questão que permanece em aberto em nosso momento pós-estruturalista e pósdesconstrucionista, o que ainda está para ser dito e pensado é, pois, o ponto de vista indigena sobre essas linhas. A possibilidade de pensar filosoficamente esse impensado tem finalmente começado a tornar-se possível através do trabalho de revisão e recuperação do pensamento de Lévi-Strauss aliado à emergência dos conceitos indígenas na obra do antropólogo Eduardo Viveiros de Castro e de outros etnólogos que passaram a expor para nós o pensamento ameríndio. ${ }^{4}$

Inspirada nessa nova antropologia e relacionando-a à teoria da literatura, em especial à proposta por Luiz Costa Lima em sua revisão do conceito de mímesis, proponho reler as linhas Nambikwaras não como farsa, mas como força, como uma lição de escritura artística. Minha hipótese é que as linhas Nambikwaras, tortas e sinuosas, podem ser lidas como o grau zero do jogo ficcional, e podem revelar a estrutura daquilo que nossa cultura chama ficção e, por extensão, arte. Nessa leitura, então, o antropólogo estrutural não seria (apenas) Lévi-Strauss, mas também o próprio chefe Nambikwara.

A lição de escritura é, assim, a cena de origem de meu texto, e a cena de origem (de um livro em planejamento) que vai me permitir pensar a literatura brasileira e latino-americana a partir dela como sua variação. Comentando Lévi-Strauss, diz Derrida: "Mas a cena não era a cena de origem, apenas a de imitação de escritura". Proponho, porém, repensar a cena enquanto cena de origem, mas não da imitação e sim do jogo mimético, baseada na noção de mímesis como "produção de diferença", proposta por Luiz Costa Lima, e na noção de "economia simbólica da alteridade", proposta por Eduardo Viveiros de Castro.

3. Ver SOUZA e FAUSTO. Reconquistando o campo perdido, p. 90-91.

4. Apesar de não ser o foco de meu estudo, outra contribuição fundamental para a compreensão do ponto de vista indígena vem dos estudos sobre as práticas de escritas nas Américas, como o trabalho de Gordon Brotherston e sua proposta de uma "gramatologia do Novo Mundo", à qual farei referência mais adiante.

5. DERRIDA. Gramatologia, p. 157. 
Importante assinalar que Viveiros de Castro foi aluno de Costa Lima, que o apresentou à obra de Lévi-Strauss, por sua vez presença fundamental em sua tese Estruturalismo e teoria da literatura, de 1970. O que estou fazendo é um retorno a essa fonte: Lévi-Strauss, promovendo um reencontro entre Costa Lima e Viveiros de Castro como nomes de duas disciplinas em contato: teoria da literatura e antropologia. Meu intuito é avançar por linhas ainda a demarcar, e que se concentram em duas direções principais: refletir sobre as bases teóricas para a proposta de uma "antropologia da ficção"; e desenvolver o conceito "escritas de ouvido", que, partindo da intersecção escrita-oralidade, visa atingir o núcleo de uma mímesis que parte não do olho, nem da mão, nem da boca, mas da escuta na escrita. ${ }^{6}$

Proponho então o seguinte caminho para esse texto, que ensaia uma primeira aproximação ao tema: 1) rever a cena, o mito de origem da "lição de escritura", onde ocorreu e quais suas circunstâncias; 2) relembrar a interpretação proposta por Lévi-Strauss e, muito brevemente, a contrainterpretacão de Derrida; e 3) reinterpretar a cena entre Lévi-Strauss e o índio a partir da teoria da mímesis e do pensamento ameríndio. Antes, porém, importa saber o que é, ou como ocupar um ponto de vista nativo. Para isso, vou sugerir alguns pontos possíveis para uma aproximação entre a teoria literária e antropologia.

\section{Pensando a literatura como nativa}

Levando em conta os estudos sobre a presença dos indígenas na literatura brasileira e latino-americana, minha pesquisa toma uma direção paralela, mas distinta: busco repensar a literatura de matriz ocidental a partir de uma teoria não ocidental, ou melhor, busco repensar a literatura não indígena com um pensamento indígena, produzindo uma aproximação ressoante entre ambos, e esperando que algo brilhe a partir desse contato.

Tento assim de certo modo estranhar nosso modo de pensar a literatura, propondo revê-lo sob a perspectiva nativa, ou seja, incorporando o pensamento ameríndio, e, a partir do que aprendo com esse pensar, sugerir a possibilidade de tornarmo-nos nativos da literatura e seus mundos, como se

6. Sobre a noção de "antropologia da ficção", ver o primeiro capítulo de meu livro Maranhão-Manhattan. Sobre a noção de "escritas de ouvido", ver Librandi-Rocha. Writing by ear. 
fosse possível passarmos para "o lado de lá" a cada ato de leitura, assim como faz o etnógrafo quando em seu trabalho de campo. Ocupar o ponto de vista nativo significa, assim, a situação paradoxal de tornar-se estrangeiro em relação ao seu próprio pensamento, estranhando-o, e ao mesmo tempo tornar-se nativo de um pensamento estrangeiro, borrando os limites entre ambos. Para tornar esse exercício possível, começo a perceber que é preciso alterar o modo de escrita, o que significa incorporar na crítica literária uma certa dose de ficção, e praticar aquilo que antropólogos australianos vêm chamando de "fictocriticism". ${ }^{7}$ Esse movimento é necessário não por querer emular a ficção, mas para poder avançar além ou aquém do que a razão nos permite pensar, e conseguir assim, de certo modo, descontrolar o controle do imaginário.

Assim, se, antropólogica e antropofagicamente pensar como nativo significa ocupar um ponto de vista estrangeiro ao nosso próprio pensamento, a antropologia que vem se destacando hoje é aquela que está produzindo a descolonização de seu próprio pensar e mergulhando em outro regime de conceitos. Essa nova direção proposta pelo brasileiro Eduardo Viveiros de Castro, o americano Roy Wagner e a britânica Marylin Strathern, entre os nomes mais salientes, está propondo uma equivalência epistemológica entre os mundos que Marshall Sahlins bem denominou como the West and the rest para denunciar seu desequilíbrio. O que essa nova antropologia busca é uma equivalência baseada na afirmação de uma radical diferença. O pensamento ameríndio ou melanésio é distinto do nosso, dizem eles, não porque tenham distintos pontos de vista sobre os mesmos objetos, mas porque os mundos que eles pensam são outros. Assim, trata-se de descrever e inscrever a diferença desse pensamento. Como diz Strathern, não é possível falar do outro com o seu código, mas apenas através do nosso. É possível, porém, tentar que o outro fale através de nós, atravessando-nos, criando brechas e inversões, "obviações" em nosso pensar-dizer, interrompendo-nos, e fazendo aparecer coisas que nós não somos capazes de ver ou dizer. ${ }^{8}$ Para isso, é preciso sofrer uma transformação: é preciso que um pensamento outro fale pela nossa boca a partir de um experimento antropológico ficcional, ou, o que é ainda mais preciso, a partir de uma filosofia produzida pela antropologia. Esse ponto é importante e será retomado adiante quando falarmos da diferença de leituras entre o antropólogo

7. Termo usado para definir o estilo dos textos e do pensamento de Michael Taussig assim como o de seu colega Stephen Muecke.

8. Cf. STRATHERN. No limite de uma certa linguagem. 
Lévi-Strauss e o filósofo Derrida, e também quando realçarmos qual tipo de filosofia se pode depreender de uma teoria literária renovada pelo pensamento ameríndio. O que essa nova teorizacao antropológica extremamente complexa está propondo, então, é um equilibrio epistemológico entre o pensamento ocidental e pensamentos de povos estranhos a essa tradição, produzindo um contato e uma comparação baseados em suas diferenças e não em busca de suas semelhanças. Como diz repetidamente em seus textos Viveiros de Castro, a questão não é ter um ponto de vista distinto sobre as mesmas coisas, mas pensar com um pensamento diferente para compreender outras potencialidades das coisas e experimentar outras imaginações.

Experimentar outras imaginações é o que a ficção produz continuamente como possibilidade e exercício. No entanto, por que, apesar de nossos melhores teóricos, os estudos literários continuam a ocupar uma posição menor (cada vez mais desqualificada e em vias de desaparecimento) em relação a outros campos de trabalho e de atuação? Por que é tão difícil deixar de pensar a ficção como um segundo produto e dar-lhe direito de existência plena? Por que a literatura de ficção continua menosprezada mesmo quando louvada?

Talvez, o pensamento corrente e dominante no West não nos permita pensar a ficção, que seria similar ao rest. É em relação a esse ponto que sugiro uma hipótese que me pareceu surpreendente: talvez haja uma espécie de incompossibilidade entre nossos artefatos artísticos e nossas epistemologia, cosmologia e ontologia. Se essa hipótese for válida, heuristicamente, por que não supor que outras diferentes epistemologias, cosmologias e ontologias possam ser mais afins aos nossos textos literários?

De modo geral e redutor, o que nossa "pop-filosofia moderna", como diz Viveiros de Castro, aquela que instaurou os grandes divisores natureza/cultura, física/metafísica, texto/contexto, nos diz? Que nossos textos literários, nossos objetos ficcionais, são muito bons, excelentes mesmo, mas de pouca utilidade, pois, afinal, criam mundos que não existem, sendo "apenas" representação imaginária. Como

9. Ver VIVEIROS DE CASTRO, Metafisicas canibales. 
seres inteligentes e racionais, sabemos que não há nenhum corpo ali, signos são abstrações, e o mundo está alhures. Seria infantil mantermo-nos no modo deceptivo. Sentimos, mas é assim: a vida é dura, e o resto é literatura. Parece, assim, que a literatura ocupa e é pensada como lugar do excesso: ou é um luxo (excesso entendido como ócio) ou, seguindo a imagem do poema concretista, é um lixo (excesso descartável em relação ao que é tido como útil). A raiz desse menosprezo (ou a oscilação entre a mais-valia e a menos-valia) vem de que em nosso pensar habitual funciona assim: nós existimos, os personagens, não; nós somos seres de carne e osso, eles são seres de papel; nós pensamos, eles são imaginários; nós agimos, eles são nossa projeção; nós temos e fazemos história, eles são estória de "mentira".

Ocorre, porém, que há um pensamento diferente no mundo amazônico e ameríndio. Um pensamento que advoga o perspectivismo (que não é o mesmo que relativismo) e o multinaturalismo (reverso do multiculturalismo), e que é mais afim ao mundo imaginário da ficção porque mais próximo do que sonha a nossa melhor filosofia. Assim, se a "insurreição e alteração começam pelo conceito", ${ }^{10}$ diria que no campo dos estudos literários é o conceito de literatura ou nosso modo de pensar a ficção que deve ser continuamente alterado e repensado, é em busca dessa renovação que nos últimos anos venho tentando repensar o campo da teoria da literatura a partir da antropologia ameríndia, pois o que eu aprendo com o que os antropólogos me ensinam a respeito do pensamento ameríndio e de seus modos de vida e de invenção, seus conceitos e sua cosmologia, é muito mais afim a uma reconsideração do ficcional e vem juntar-se aos nossos melhores teóricos do literário. Assim, o que Viveiros de Castro descreve como uma "ontologia política do sensível" ou um "perspectivismo ontológico" é o que estou querendo transpor para o campo da teoria da literatura. A cosmopolítica indígena, sua filosofia, que passamos a conhecer através dessa "construção experimental", é o diferencial que precisamos para nos reenergizar e renovar. Por isso, faço minhas as suas palavras e as aplico e desvio para o campo literário. Para testar a validade dessa transferência, ou apropriação de conceitos antropológico-ameríndios, para o campo da teoria literária, começo propondo algumas analogias.

Pela primeira, diria que os textos literários e os grupos indígenas ocuparam dentro da tradição ocidental uma posição similar. É possível situá-los

10. VIVEIROS DE CASTRO. "Transformação" na antropologia, transformação da "antropologia". p. 7. In: http://www.culturaebarbarie.org/sopro/ n58pdf.html. 
como análogos, não obviamente porque o indígena "não existiria" (apesar de seu constante silenciamento, etnocídio e "epistemocídio" coletivos indígenas e os coletivos de ficção foram tidos ou como adorno e exotismo ou como marginais em relação a um saber que vem de fora. Fora da ficção para dizer o que a ficção é ou não é, ou fora dos grupos indígenas para descrever o que eles faziam, mas provavelmente não sabiam. Ambos teriam, assim, um estatuto refém do que está fora ("referente", "realidade" ou "verdade"), e do que vem de fora (o colonizador). Desse modo, se essa nova antropologia propõe radicalizar uma equivalência entre o antropólogo e o nativo, ${ }^{12}$ proponho radicalizar a equivalência entre os leitores (que estão fora da literatura) e os personagens (que estão dentro da ficção) como parte de um experimento ficto-crítico. Radicalizar uma equivalência entre nós e "eles" permite-nos pensar a ficção como uma outra cultura dentro da nossa com a qual estabelecemos relação e que devemos respeitar na sua diferença.

Retomando o par nativo-estrangeiro, é como se o texto de ficcão fosse estrangeiro a nós que o criamos e que o lemos. Sugiro, pois, ler ao pé da letra a ideia de Proust retomada por Deleuze ${ }^{13}$ de que a literatura é escrita em uma língua estrangeira, assim como a ideia-chave da primeira teoria da literatura, a do Formalismo russo, do discurso literário como ostranenie, estranhamento. Busco então radicalizar essas noções, e sugerir que nos transformemos em etnólogos de nossa própria ficção. Produzidas por nós, as vozes poéticas e os personagens são nossos estranhos ou o estranho que há em nós. Eles são nossas potencialidades, que visitamos e inventamos como quem é capaz de habitar e sonhar em uma língua estrangeira.

Se, como diz Roy Wagner, "toda compreensão de uma outra cultura é um experimento com a nossa própria”, 14 sugiro que a invencão da ficção é um experimento com nossa própria cultura como outra. Pensar a ficção como uma outra cultura obriga-nos a retirar a ficção da posição secundária e subalterna, e deixarmos de ser seus colonizadores (sempre explicando a literatura em função

11. Expressão de Bob Scholte apud VIVEIROS DE CASTRO. O nativo relativo, p. 116.

12. VIVEIROS DE CASTRO. O nativo relativo, p. 126.

13. DELEUZE. Crítica e clínica, p. 9.

14. WAGNER, 1981, 12 apud VIVEIROS DE CASTRO. O nativo relativo, p. 124. 
do que ela diz sobre nós mesmos e nossa realidade) para passarmos a ser seus interlocutores (multiplicando a ficção e seus mundos, e respeitando sua diferença para aprender com ela e nos descolonizarmos de nós mesmos). Essa é a estrutura da filosofia proposta por Viveiros de Castro: considerar os índios não como objetos mas como interlocutores, para que um efetivo diálogo possa ocorrer (ou, retomando o que se disse acima, para que se crie uma filosofia capaz de ouvir): "Interlocutor dialógico mas também contrário antilógico, o pensamento ameríndio está disposto em uma relação de tensão constitutiva com sua descrição antropológica” . ${ }^{15}$ Penso que essa exata definição pode ser transposta para a relação da teoria literária com o mundo ficcional. Nesse último caso, é preciso indagar e tentar responder: se personagem não é gente, como estabelecer com eles uma relação de interlocução?

\section{Mundos paralelos}

Pelo conceito de "perspectivismo ameríndio" aprendemos que não se trata de traduzir distintas visões de mundo, mas compreender a possibilidade de distintos mundos coexistentes. Para o campo dos estudos literários, essa reformulação implica um golpe de mestre na dicotomia representação-realidade levando-nos a recriar nossa relação com a ficção como um mundo inventado, ontologicamente pensável. Nesse caso, seria preciso investigar como o perspectivismo ameríndio pode se unir ao perspectivismo teorizado por W. Iser em relação à ficção. ${ }^{16}$ A partir da autopoiesis da criação de mundos possíveis, o perspectivismo ficcional opera a duplicação de nosso mundo através do jogo iniciado pela partícula do "como se", que nos distancia e nos desobriga dos condicionantes habituais, de modo a que possamos aceder a uma visão diferenciada, a uma espécie de iluminação que nos faz rever a vida com olhos livres. No caso ameríndio, o perspectivismo não significa uma representação mental, um distinto ponto de vista sobre uma mesma realidade, mas a existência de distintas realidades a partir das quais o ponto de vista, sempre humano, demasiado humano, se situa.

O mundo ameríndio, traduz Viveiros de Castro, é um mundo unificado no qual a semiótica não está separada no sistema literal-metafórico, mas no qual

15. VIVEIROS DE CASTRO. "Transformação" na antropologia, transformação da "antropologia", p. 7. In: http://www.culturaebarbarie.org/sopro/ n58pdf.html.

16. Cf. ISER. O fictício e o imaginário. 
todo ser está relacionado a outros seres em uma "economia simbólica generalizada" baseada no processo de personificação. ${ }^{17}$ Nesse mundo unificado, há múltiplos mundos simultaneamente possíveis, nos quais cada ser, plantas, animais, personagens, espíritos, mortos, deuses, estão simultaneamente presentes e são agentes, porque cada um é pessoa no seu próprio domínio. Trata-se de um mundo de "humanidade imanente". 18 Cada ser vive em seu próprio coletivo, mas nem por isso sua província (ou o que se chama real) pode ser considerada a única verdadeira; os múltiplos mundos ecoam; basta praticar a difícil arte (para poucos) de saber ouvi-los e acessá-los. Leitores de literatura, reconhecemo-nos nesse multiverso ameríndio. Quando lemos um poema ou um romance mergulhamos em um mundo no qual a divisão real/fictício deixa de atuar, mesmo que apenas durante o tempo de leitura, como se transitássemos em mundos distintos, mas unificados.

Essas ideias são possíveis de serem pensadas porque sociedades ameríndias baseiam-se em uma economia do dom. Distinto de nosso mundo, no qual coisas e pessoas assumem a forma de objetos, no mundo da troca de dons (exchange of gifts), coisas e pessoas assumem a forma de pessoas. ${ }^{19}$ Para conhecer é preciso considerar nossos "objetos" de pensamento como pessoas. Se não se personifica, diz Viveiros de Castro, não se entende nada, não se estabelece uma relação de interlocução, mas de domínio. Como diz Strathern: "O próprio ato de interpretação pressupõe a personificação do que está sendo interpretado”. 20

Nossos escritores sabem disso. João Guimarães Rosa disse duas coisas sobre sua obra-prima, Grande sertão: veredas. Uma: "Riobaldo é meu irmão". Duas: "literatura tem de ser vida". E se levarmos a sério, como um programa intelectual, a afirmação de Guimarães Rosa: "literatura tem de ser vida"? Se levarmos essa afirmação a sério (e também com humor), o que acontece? Acontece que outras perguntas começam a aparecer, perguntas que não podemos fazer em nosso regime habitual de pensamento, porque seriam e são classificadas como loucas e incompetentes. Por exemplo: que tipo de vida possui um personagem de ficção?

17. VIVEIROS DE CASTRO. The gift and the given, p. 246.

18. VIVEIROS DE CASTRO. The gift and the given, p. 250-51.

19. VIVEIROS DE CASTRO. The gift and the given, p. 246.

20. STRATHERN apud VIVEIROS DE CASTRO. The gift and the given, p. 249 (tradução minha).

21. ROSA. Diálogo com Guimarães Rosa, p. 67. 
Uma vida imaginária configurada no texto? Certo. Mas o que isso quer dizer? É verdade que a ficção produz seres que não morrem. Parafraseando Barthes, não há razão para que um dia a gente pare de falar de Romeu e Julieta, de Madame Bovary, de Riobaldo, ou de Borges, personagem e autor de si mesmo enquanto outros. É verdade também que os personagens não têm como alterar seu destino já escrito, nem as palavras pronunciadas, mas nós nos relacionamos com eles, e nessa relação eles e nós nos alteramos mutuamente.

Como diz em um texto incrivelmente importante a pesquisadora Wai Chee Dimock, o texto literário, diferentemente de outros textos, muda com seus leitores, o que a leva a conceituar o discurso literário como uma "ontologia instável”. Basta lembrar que o Quijote de Borges/Pierre Menard não é o mesmo Quijote de Cervantes, apesar de o texto ser idêntico. Por quê? Porque o texto muda com o tempo e reverbera a inscrição histórica de quem o está lendo. Assim também ocorre quando lemos e relemos grandes textos e poemas, pois os personagens não mudam de sina, mas a cada releitura aparecem diversos da leitura anterior. Por quê? Talvez seja preciso redescrever essa impressão no âmbito de uma ontologia do ficcional como um mundo de presenças latentes. ${ }^{22}$

\section{A literatura como vivência}

Isso me dá a liberdade inventiva de pensar a literatura como vivência. Ler a literatura assim é um ato político de intervenção: é ter acesso e ser acessado por outras vidas. Posso então sugerir que ler literalmente é, paradoxalmente, ler contra a letra, colocar a letra do avesso, como a bela imagem de Robert Harrison em seu livro Forests. As pedras, diz ele, têm uma dupla vida. As pessoas da cidade veem apenas a parte visível a ser usada como material para construção de prédios (ou de hidroelétricas como as que querem acabar com os rios e os povos da Amazônia). Mas os provincianos, diz Harrison (e os indígenas, os ribeirinhos e outros que vivem às margens das cidades), sabem que é preciso virar as pedras para cima. Só então veremos a vida de insetos, larvas e formigas que se escondem por baixo delas. Proponho que ler literatura como vida funciona assim também: a

22. Penso nos conceitos de "presença" e de "latência" como vêm sendo elaborados por H. U. Gumbrecht. Ver seus livros Presence e Latenz. No texto "Nuvens Invisíveis", analiso o mundo de nuances e de latências expresso no conto "Nenhum, Nenhuma", de J. Guimarães Rosa. 
cada vez que viramos as páginas do livro, vemos vida pulsante ali dentro. E quando lemos ajudamos essas vidas literárias a emergirem. É o mundo dos avessos.

\section{O corpo da ficção}

Nesse caso, para entender o ponto de vista de outrem é preciso assumir seu corpo, "encorporá-lo", pois o conceito de corpo ameríndio é um conceito não biológico, mas metamórfico, como uma roupa que se veste e se desveste, a depender da situação e dos encontros passíveis de alteração. ${ }^{23}$ Essa mesma noção é expressa por Clarice Lispector no jogo ficcional que se estabelece entre ela e o narrador Rodrigo S. M., seu duplo: "Nestes últimos três dias, sozinho, sem personagens, despersonalizo-me e tiro-me de mim como quem tira uma roupa. Despersonalizo-me a ponto de adormecer". ${ }^{24}$ Se o corpo ameríndio é uma veste transformacional, parte de uma cosmologia na qual um jaguar pode se transformar em meu cunhado e vice-versa, o mundo da ficção também é, como definiu Karlheinz Stierle, um mundo marcado pela metamorfose, outro conceito da teoria da literatura a ser repotencializado pelo pensamento ameríndio. Outros conceitos do campo literário a serem repensados incluem as noções de dialogismo e polifonia bakhtinianos, e o conceito de estranhamento. Pois, a partir do momento em que o pensamento ameríndio é levado a sério, e suas concepções traduzidas em conceitos epistemologicamente tão válidos como noções da filosofia ocidental, podemos adotar seus conceitos para repensar o mundo da ficção. Assim, se no mundo ameríndio considera-se que todos (ou quase todos) são humanos em corpos distintos, isso nos permite indagar que tipo de corpo tem um personagem de ficção? Ou qual corporalidade envolve nossa relação com a ficção e a poesia? ${ }^{25}$ Vou propor o seguinte. Para falar e ser ouvido, um personagem na página precisa do corpo de seus leitores para interagir, para criar uma comunidade, de modo que esse ser sem agenciamento individual possa agir, e sua voz possa ser ouvida. É assim que, se a antropologia é filosofia com pessoas incluídas ("anthropology is philosophy with the people in", no original de Tim Ingold ${ }^{26}$ ), sugiro que a teoria

23. Ver VIVEIROS DE CASTRO, The gift and the given.

24. LISPECTOR. A hora da estrela, p. 80-81.

25. Agradeço essas questões sugeridas por Roberto Zular.

26. INGOLD apud VIVEIROS DE CASTRO. O nativo relativo, p. 127. 
da literatura é filosofia com vida reverberando entre nós (leitores e textos). ${ }^{27}$ Estabelecidas essas analogias entre teoria, ficção e antropologia, passo então a ler o traço Nambikwara como uma inscrição que nos permite ver possibilidades latentes em nossa relação com o texto literário.

\section{A cena}

Relembro rapidamente o episódio. Trata-se de uma cena de troca: produtos da "civilização" seriam trocados por artefatos indígenas. Lévi-Strauss e o chefe Nambikwara estão ambos diante de setenta e cinco índios em uma situação tensa: "Diversos indígenas pareciam jamais ter visto um branco e sua acolhida rebarbativa, o nervosismo manifesto do chefe, sugeriam que ele os trouxera um pouco à força". É então que ocorre um "extraordinário incidente". Antes de relatálo, Lévi-Strauss explica que, comparados aos Caduveo e aos Bororo, os Nambikwara parecem "uma infância da humanidade" (p. 290), pois, diferente das outras tribos, esse grupo não conhece a cerâmica; eles não têm canoas, nem dormem em rede; não sabem escrever nem tampouco desenham. No entanto, antes de começarem a troca de presentes, o chefe pede um bloco de papel, e quando Lévi-Strauss the pergunta alguma coisa:

ele não me comunica verbalmente as informações que lhe peço, mas traça sobre o seu papel linhas sinuosas e mas apresenta, como se ali devesse ler a sua resposta. (...) está tacitamente entendido entre nós que os seus riscos possuem um sentido que eu finjo decifrar; o comentário verbal segue-se quase imediatamente, e me dispensa de pedir os esclarecimentos necessários.

Quando todos os índios estão reunidos para a troca dos presentes, a mesma cena se repete (como se a anterior fosse um ensaio antes da grande encenação diante dos espectadores):

27. Veja-se a tradução com o comentário de Viveiros de Castro sobre a definição de Ingold: "Uma filosofia com outros povos dentro, então: a possibilidade de uma atividade filosófica que mantenha uma relação com a não-filosofia - a vida - de outros povos do planeta, além de com a nossa própria”. O nativo relativo, p. 127. 
Ora, mal havia ele reunido todo o seu pessoal, tirou dum cesto um papel coberto de linhas tortas, que fingiu ler, e onde procurava, com uma hesitação afetada, a lista dos objetos que eu devia dar em troca dos presentes oferecidos...

Como uma cena teatral e performática, o chefe "finge ler", e Lévi-Strauss classifica a cena como uma "comédia":

Essa comédia se prolongou durante 2 horas. Que esperava ele? Enganarse a si mesmo, talvez; mas, antes, surpreender os companheiros, persuadilos de que as mercadorias passavam por seu intermédio, que ele obtivera a aliança do branco e participava dos seus segredos.

O que está em jogo nessa cena? Como se percebe, aparentemente o chefe indígena age como um trickster tropical nos tristes trópicos fingindo que lê e escreve algo inteligível para mostrar que domina o conhecimento e a linguagem ocidental ao desenhar linhas tortas no papel. Lévi-Strauss não recusa, mas aceita esse jogo que irá pôr em questão a instituição da escrita. Por quê? Estranhando seu código pelo afastamento cômico produzido pelo falso texto, Lévi-Strauss vai ler o engano dos traços indígenas no papel como revelando o engano maior causado pela escrita que escraviza e faz com que impérios se sustentem: "Não se tratava de conhecer, de reter ou de compreender, mas de aumentar o prestígio e a autoridade de um indivíduo - ou de uma função - à custa de outrem" - era isso que o "indígena ainda na idade da pedra adivinhara". O intuito da argumentação é mostrar que os traços do indígena no papel invertem a relação de aprendizado. Quem aprende a lição de escrita é ele, Lévi-Strauss, e sua intenção é destruir o argumento da superioridade da civilização do Ocidente e da escrita sobre esses indígenas "da idade da pedra".

Lévi-Strauss interpreta a cena como revelação de uma função (oculta) da linguagem escrita: a dominação intensiva e por longos períodos de tempo de um grupo sobre outro, a sujeição à lei e ao Estado, a manutenção de escravos e a proletarização. Essa seria a função primeira da escrita que o gesto do índio revelaria. As outras funções, a função de produzir e de armazenar conhecimento, a função de planejar o presente e o futuro, e a função de produzir prazer estético seriam secundárias em relação a essa função primeira, podendo muitas vezes serem usadas para reforçar (e não para criticar) a função primeira da escrita. Escrever, diz LéviStrauss, "parece ter favorecido mais a exploração de seres humanos do que sua 
iluminação intelectual." E continua: "Se minha hipótese for exata, é preciso admitir que a função primária da comunicação escrita é facilitar a servidão".

O uso do termo "função" por Lévi-Strauss parece remeter aos estudos do Círculo Linguístico de Praga, que estabeleciam a função não como uma propriedade "mas um modo de utilizar as propriedades de um certo fenômeno". 28 Derrida criticará Lévi-Strauss por ele condenar a escrita em oposição a uma fala supostamente inocente, repropondo assim a divisão etnocêntrica de povos com ou sem escrita, mas, ao usar o termo função, vemos que Lévi-Strauss está se referindo a um dos modos de utilizar a escrita que, segundo ele, é tanto mais dominante quanto mais se mantém oculto. O que ele condena é a escrita como produtora de cemitério e cadeia, a relação entre império-morte-sujeição mediados pela cachaça veneno-remédio da escrita. ${ }^{29}$

\section{Derrida}

Para o propósito desse texto, em relação a Derrida vou apenas dizer que sua leitura tem o mérito de unir o antropólogo e o nativo, pois tanto a escrita alfabética como o traço indígena são considerados como escritura, e estariam ambos submetidos à deriva da différance, uma arquiviolência inicial que nos separa do vocativo absoluto de uma fala plena. No entanto, para quem quer pensar a escritura indígena e o ponto de vista nativo é a obra de Lévi-Strauss que nos permite pensar a diferença. Gordon Brotherston, em um ensaio pioneiro na análise da oposição entre Lévi-Strauss e Derrida, sugere usar o melhor de ambos para o campo dos estudos das escritas ameríndias, criando assim "a possible grammatology (Derrida) of America (Lévi-Strauss)". E reconhece: "In the first place this involves firmly establishing the New World as a term in its own right, beyond its role as a mere correlative for European philosophy. Few have done this better than Lévi-Strauss, in a famous paragraph from 'Race and history'..."

Não é estranho? A différance de Derrida não nos deixa pensar a diferença, pois afirma a semelhança. Já antropólogos como Marylin Strathern chegam

28. Mukarovsky apud Costa Lima. Poesia e experiência estética, p. 43.

29. Faço aqui referência ao provérbio quilombola citado por Lévi-Strauss nesse mesmo capítulo: "Cemitério, cadeia e cachaça não é feito para uma só pessoa".

30. BROTHERSTON. Towards a grammatology of America, p. 203. 
a dizer que não é apenas necessário afirmar a diferença como é preciso radicalizála se quisermos entender outrem. Ela diz que "escolheu exagerar deliberadamente as diferenças, simplesmente porque isso nos obriga a parar para pensar", ${ }^{31}$ e assim poder entender outras concepções, outras descrições e outras imaginações logicamente distintas da nossa.

Do mesmo modo, na economia simbólica da alteridade ameríndia, proposta por Viveiros de Castro, e na mímesis revisitada por Costa Lima, a base de semelhança existe para fazer falar e aparecer a diferença. Costa Lima reavalia um conceito central do Ocidente, a mímesis, reconceitualizando-o a partir de uma perspectiva à margem; ${ }^{32}$ Viveiros de Castro acentua o pensar ameríndio em contraposição ao pensar ocidental colonial, como um pensar com o qual temos de aprender não porque sejamos "corruptos" e eles "inocentes", mas porque nos abre as portas de outros mundos quando o nosso está em vias de desaparecer por produzir destruição. O desafio é pensar ambos conjuntamente: de que modo a epistemologia da mímesis por Costa Lima pode se encontrar com a ontologia da diferença ameríndia? Qual mímesis está implicada no canibalismo como incorporação da diferença para in-definição de uma identidade que tem no outro seu ponto de fuga? Qual ontologia está implicada na mímesis de produção da diferença? Como diz Costa Lima, as obras miméticas "produzem 'seres' no próprio ato de formulálos [pois] a mímesis de produção tem um caráter imediato e eminentemente performativo", ${ }^{33}$ como veremos agora na releitura da lição de escritura.

\section{Arte}

Se a lição da escritura ensina que a função primeira da escrita é subordinar e sujeitar, meu objetivo é mostrar que essa mesma lição também ensina outra coisa. Como vimos, a cena entre o antropólogo e o indígena compõe uma "farsa", uma "encenação", um teatro. Para Lévi-Strauss, o índio produz uma imitação, e sua meta é aumentar seu poder sobre o grupo. Na minha leitura, proponho

31. STRATHERN. No limite de uma certa linguagem, p. 173.

32. Cf: "e talvez sobretudo porque pensamos a partir de uma área marginalizada, temos a oportunidade de tematizar a questão. Mas não se trata de fazer o elogio de viver na margem (...)". COSTA LIMA. Vida e mimesis, p. 299.

33. costa lima. Vida e mímesis, p. 278. 
perceber o potencial mimético dessa cena ou o que essa cena nos ensina sobre a função mimética. Minha questão é: como podemos ler essas marcas não em relação ao que elas revelam sobre a imitação do poder da escrita, mas sobre o que elas revelam em relação à escrita artística? Em outras palavras: que tipo de mímesis está envolvida na "farsa", na encenação do chefe indígena que finge escrever diante do antropólogo? É apenas uma imitação e uma cópia falhada, ou seria exagerado dizer que esse traço põe "a máquina da mímesis em funcionamento"? Como já disse, minha hipótese é que essa cena pode ser lida como o grau zero do jogo mimético, fazendo-nos lembrar alguns dos aspectos mais sutis envolvidos na experiência estética.

A escrita alfabética condenada por Lévi-Strauss é revista a partir de uma outra escrita, a da inscrição em uma cena de troca. O fato é que esse falso texto escrito põe em questão a verdadeira escrita ou põe em questão a verdade da escrita. O truque do trickster indígena abala os fundamentos da escrita. Ele imita para ser igual ao antropólogo, e ter o mesmo poder de decifrar letras, mas seu gesto produz no receptor uma diferença, a consciência da farsa. O texto sem letras faz, assim, falar o "frame" que move a cultura letrada pela sua subversão cômica. Digamos que a arte nasce do gesto do índio; a mímesis artística tem como arquétipo esse gesto inconsequente, o de uma cópia que vai se transformar em mímesis, pois a partir de uma base de semelhança produz uma diferença. Seu gesto também cria instabilidade semântica, que vai gerar o esforço interpretativo de Lévi-Strauss no momento de insônia. O sonho do índio (escrever como os brancos) vai acordar o antropólogo de seu sono e despertar a crítica de sua cultura de origem: "Ainda atormentado por esse incidente ridículo, dormi mal e enganei a insônia rememorando a cena das trocas".

\section{Poesia e experiência estética}

No ensaio "Poesia e experiência estética", Luiz Costa Lima aborda nossa dificuldade em definir o que é poesia como uma dificuldade intrínseca à própria poesia, porque o poema implica uma experiência que elimina a distância entre sujeito e objeto, ao mesmo tempo em que produz o distanciamento do eu.

34. Costa LIMA. Entrevista, p. 344. 
A poesia é um movimento antinarcísico, o que significa a experiência de o eu experimentar-se como outro. Para definir a poesia é preciso então refletir sobre como experimentamos a poesia. É em relação a esse difícil exercício que o texto de Costa Lima nos oferece algumas respostas-chave. A primeira delas, que eu gostaria de sublinhar, afirma que a experiência estética implica "a suspensão provisória do império do semântico".

Em nosso cotidiano, estamos sujeitos ao "império do semântico": é preciso compreender as mensagens que estamos constantemente recebendo e enviando para que a vida funcione e para evitar o caos. No entanto, para que a experiência estética ocorra é preciso que, por um momento, apenas por um momento, um mínimo caos se dê, uma pequena crise ocorra. Esse intervalo é o momento da suspensão semântica, quando nos aliviamos do peso das mensagens, e sentimos uma espécie de suspensão ou leveza (mesmo quando lemos os poemas mais tristes), suspensão que ocorre e dura apenas um curto intervalo de tempo. Esse momento de suspensão ocorre quando uma certa configuração sintática atrai nossa atenção e nos distrai do significado, fazendo-nos sentir, por um momento, suspensos no vazio.

Quando esse pequeno intervalo ocorre, expõe Costa Lima, confrontamo-nos com os limites do conhecido e beiramos o desconhecido. A experiência estética gera assim uma crise, porque ela nos mostra os limites da razão, como uma experiência que permite a penetração de algo que a razão não nos deixa compreender. Desse modo, na experiência estética, o movimento vai de um momento de suspensão para um momento de suspeita (entendido como a reocupacão semântica posterior através de uma reaproximação crítico-interpretativa).

Gostaria de reter essa aguda definicão da experiência estética como um momento de suspensão seguido de um momento de suspeita, e realçar estas três outras passagens: 1) a experiência estética é comparável "a uma perda de peso, provocada por qualquer evento que nos faça perder o sentido de orientação, sem que, por isso, nos desatine"; ${ }^{36}$ ) "as artes constituem a única forma discursiva em que... a comunicação não é o vetor primordial", e 3) "sua vitalidade está na resposta que provoca, não na mensagem que transmite". Com essas idéias em mente, voltemos à cena entre o antropólogo e o indígena.

35. COSTA Lima. Poesia e experiência estética, p. 46-47.

36. Costa lima. Poesia e experiência estética, p. 48.

37. Costa lima. Poesia e experiência estética, p. 52. 
Pelo aspecto da suspensão e da suspeita, notamos que as linhas tortas do índio são um excesso em relação ao momento da suspensão semântica, porque não há nenhuma mensagem inscrita ali. Não se trata de um poema, nem mesmo de um desenho. Lévi-Strauss vê as linhas e imagina um sentido (por exemplo: arcos a serem trocados por um facão); o índio vai dizer sim ou não, e essa encenação vai continuar por duas horas. Ao produzir esse excesso de "suspensão do império do semântico", essas linhas geram uma crise no seu receptor, gerando a "lição". Lévi-Strauss aprende algo importante sobre a escrita; algo que até então nunca tinha aparecido com tanta clareza para ele antes dessa experiência, que ele vai interpretar em um texto, seu livro, que toma a forma de um ensaio (que seria preciso analisar). Ou seja, a suspensão total do significado gera uma crise também radical no receptor, que, sem poder dormir, rememora o ocorrido, e então o reocupa semânticamente através de uma crítica generalizada à função da escrita.

Quanto ao aspecto da perda do sentido de orientação, podemos dizer que é exatamente isso que ocorre com Lévi-Strauss logo após o "extraordinário incidente": "Sem que o percebesse, vi-me de repente sozinho no mato, desorientado". ${ }^{38}$ É assim que à cena "grotesca" do chefe escrevendo, segue-se a cena "ridícula" do antropólogo perdido. Lévi-Strauss perde seu burro, suas armas e seu material fotográfico. Quando então ouve vozes de dois índios que "tinham voltado sobre seus passos", e o tinham rastreado: "encontrar o meu material foi para eles brincadeira de criança". Os índios, que não sabem escrever, sabem rastrear as linhas marcadas no terreno, relação que também mereceria uma análise à parte.

Quanto aos terceiro e quarto aspectos ressaltados: o de que a arte não tem a comunicação como seu principal vetor, e sua vitalidade reside na resposta que provoca, diria que as linhas Nambikwara são "extraordinárias" porque solicitam uma interação performática entre ambos os atores, Lévi-Strauss e o índio, para produzir um resultado conjunto. Sem essa interação não há "encenação". LéviStrauss finge ler, e lê em voz alta, e o índio finge escrever; na junção colaborativa dos dois se produz a lição de escritura. Como diz Costa Lima: "A mímesis de produção tem um caráter imediato e eminentemente performativo". " Nesse sentido, é o espaço do silêncio e do vazio (aqui representados pelo risco de linhas onduladas) que faz as vozes ao redor do texto funcionarem.

38. LEVI-STRAUSS. Tristes trópicos, p. 315.

39. Costa lima. Vida e mímesis, p. 278. 


\section{Ressonância}

Lévi-Strauss diz que havia um entendimento tácito entre ele e o chefe indígena sobre o fato de que ambos estariam representando uma cena baseada em um roteiro mudo. Posso dizer que essas linhas "dirigiam" sua interação através de um texto imaginário escrito em lugar algum. Era um puro silêncio reverberante. Um gesto ondulatório que é possível comparar ao modo como desenhamos ou representamos ondas sonoras. Posso então dizer que essas linhas representam o grau zero de experiência estética, se considerarmos que o grau zero da poesia e da ficção é nada mais nada menos que uma reverberação, ou a ressonância de um movimento.

É esse aspecto que me interessa desenvolver para poder descrever o efeito sutil de personagens de ficção em um texto: a impressão de que ouvimos suas vozes. Não podemos ouvi-los, mas é como se isso fosse possível. Esse efeito (ou desejo) é traduzido pelo gesto do índio que espera escutar algo das linhas que ele mesmo rabiscou. Lévi-Strauss conta que o chefe esperava um retorno sonoro de suas linhas e ficou decepcionado por sua mudez. Ele esperava receber de volta um som, uma voz dizendo-lhe alguma coisa: "Ele próprio como que se ilude com a sua comédia; cada vez em que a sua mão termina uma linha, examina-a ansiosamente, como se a significação devesse brotar, e a mesma desilusão se pinta no seu rosto".

Quando lemos ficção, estamos imersos em uma expectativa similar. Um personagem de papel não fala, não tem corpo, e é mudo. Mas quando lemos uma novela ou um conto ou um poema, essa mudez reverbera em silêncio na nossa mente. A voz implícita, cosa mentale, voces paginarum, como diziam monges medievais, tem o efeito de um murmúrio, de um lamento, ou de um apelo. Para falar e para ser ouvido, o personagem no papel precisa da atuação ativa dos leitores, que precisam interagir, criar uma comunhão para que esse ser sem voz fale. Essa magia de cooptação é o que o texto escrito de ficção produz mais do que qualquer outro texto. Somos levados para dentro desse mundo sem fundo, da pura superfície das letras, e aquelas formas escritas ganham vida ao serem lidas.

Esse aspecto sonoro, aural, da mímesis escrita e silenciosa aparece no ensaio de Costa Lima sobre "Poesia e experiência estética" em dois momentos importantes. Na abertura do texto, encontramos a seguinte epígrafe, retirada de um verso do poema "Pieces" de Wallace Stevens: "There is a sense in sounds beyond their meaning”. Quase ao final de seu texto, Costa Lima exemplifica a 
qualidade da imagem poética citando Óssip Mandelstam, quando o poeta diz que o olho é um "órgão dotado de acústica", ou seja, que "o olho é capaz de ouvir". 40 Em seu livro Lines, Tim Ingold discute em certo momento "Como a página perdeu sua voz". Ele cita uma história contada pelo antropólogo Peter Gow ocorrida entre os Piro da Amazônia peruana: "A história refere-se a um indivíduo, Sangama, conhecido como o primeiro homem Piro a aprender a ler". Esse índio descreveu a leitura assim: "Eu sei como ler o papel... Ele fala comigo... O papel tem corpo...". Outro grupo indígena, os Panoans, diz Ingold, "usam a charmosa expressão 'o papel fala [com a gente]' "; ocidental... o papel não é mais do que uma superfície sobre a qual se projetam imagens gráficas de sons verbais. Sangama, porém, não via imagens de sons; ele ouvia os próprios sons falarem, como se estivessem dirigindo-se a ele diretamente. Ele ouvia com seus olhos...” Como se vê, poetas e índios têm uma relação similar com a escrita e a leitura como escuta. A reverberação é importante para entender o efeito de encantamento produzido pelo texto literário de ficção, como mana que emana da página escrita e produz "the magic voice of a book". ${ }^{43}$

\section{Conclusão}

Se esse "evento extraordinário" é comparável a uma experiência estética, posso agora reverter a direção de meu argumento e dizer que a experiência estética é comparável ao encontro entre um antropólogo e um nativo. Esse encontro significa: deixar de lado seu conhecimento adquirido - por um momento - e conectar-se a alguém ou algo que escapa ao seu saber. Nesse encontro, é preciso confrontar-se com o desconhecido; é preciso experimentar o outro, é preciso sofrer uma metamorfose.

De modo similar, Costa Lima propõe que impulso mimético na arte corresponde a um processo de transformação ou de metamorfose em função de um apelo e de um impulso pelo desconhecido: "se a obra da mímesis fascina é

40. Costa lima. Poesia e experiência estética, p. 53.

41. INGOLD. Lines, p. 34; 36 (tradução minha).

42. INGOLD. Lines, p. 36-37 (tradução minha).

43. Cf. MENARD. 
porque ela diz o que não sabe plenamente". ${ }^{44}$ Finalmente, nesse encontro com o desconhecido, a arte produz a distância do eu, é um momento antinarcísico. Assim, diz ele, o impulso básico da mímesis na arte é o de "experimentar-se como outro," o que implica "um processo de experimentação da alteridade, enquanto fascinante e desconhecida". ${ }^{46}$ E ele conclui com uma frase crucial: "Antes que espelho, do ponto de vista do sentido a mímesis é miragem". ${ }^{47}$

Finalmente, se essa hipótese funcionar, podemos pensar a escrita Nambikwara não como uma cópia falhada da escrita ocidental, mas como um tipo diferente de inscrição (aquela que o Ocidente também produz em suas ficções) e que lida com potencialidades, com latências e com silêncios: "Nos discursos da mímesis (...) o irrepresentável está sempre latente, sempre em vias de poder-se tematizar". ${ }^{48}$ Precisamente porque não produz cópia nem imitação, o jogo mimético abre a possibilidade de emergir uma diferença a partir da produção de uma miragem, que eu traduzo como reverberação e ressonância. Essa é a lição indígena da mímesis ameríndia. No silêncio de seu traço se inscreve um diferencial que desafia o pensamento.

Listening to Literature: Toward an Amerindian Literary Theory

Abstract: This essay establishes links between literary theory and contemporary ethno-anthropology, and proposes a rethinking of the notion of fiction through the use of Amerindian concepts. To demonstrate, the essay considers "The Writing Lesson" from Tristes Tropiques, and rereads the lesson not as a farce, but as force and art.

Keywords: Claude Lévi-Strauss, Nambikwaras, Eduardo Viveiros de Castro.

44. COSTA LIMA. Vida e mímesis, p. 254.

45. CELAN apud COSTA LIMA. Vida e mímesis, p. 255.

46. COSTA LIMA. Vida e mímesis, p. 254.

47. Costa lima. Vida e mímesis, p. 255.

48. Costa lima. Vida e mímesis, p. 286. 


$$
\text { Referências }
$$

BROTHERSTON, Gordon. Towards a grammatology of America. In: HAWKES, Terence (Ed.). Literature, Politics and Theory. London: New York: Methuen, 1986, p. 190-209.

COSTA LIMA, Luiz. Vida e mímesis. São Paulo: Editora 34, 1995.

COSTA LIMA, Luiz. Poesia e experiência estética. In: Intervenções. São Paulo: Edusp. p. 39-54.

DELEUZE, Gilles. Crítica e clínica. Trad. Peter Pál Pelbart. São Paulo: Editora 34, 1997.

DIMOCK, Way Chee. A Theory of Resonance. PMLA 112, 1997, p. 1060-1071.

DERRIDA, Jacques. Gramatologia. Trad. Miriam Chnaiderman e Renato Janine Ribeiro. São Paulo: Perspectiva, 2004.

HARRISON, Robert Pogue. 1992. Forests. The shadow of civilization. Chicago: The University of Chicago Press. 2003.

INGOLD, Tim. Lines: a brief history. London; New York: Routledge, 2007.

ISER, Wolfgang. O fictício e o imaginário: perspectivas de uma antropologia literária. Trad. Johannes Kretschmer. Rio de Janeiro: EdUERJ, 1996.

KAFKA, Franz. O Silêncio das Sereias. Trad. Luiz Costa Lima. In COSTA LIMA, Luiz. Mímesis: desafio ao pensamento. Rio: Civilização Brasileira, 2000. p. 368-69.

LÉVI-STRAUSS, Claude. Tristes trópicos. Lisboa: Edições 70, 1976.

LÉVI-STRAUSS, Claude. Lettre adressée à la rédaction des Cabiers pour l'Analyse, au reçu du Cahier n. 4, 'Lévi-Strauss dans le XVIIIe siècle', 1966. http:// cahiers.kingston.ac.uk/vol08/cpa8.5.levi-strauss.html.

LIBRANDI-ROCHA, Marília. Maranhão-Manhattan. Ensaios de literatura brasileira. Rio de Janeiro: 7Letras, 2009.

LIBRANDI-ROCHA, Marília. Nuvens Invisíveis. Uma Poética da Latência e da Nuance no conto Nenhum, Nenbuma, de João Guimarães Rosa. Ellipsis. Journal of the American Portuguese Studies Association. v. 9, 2011, p. 93-108.

LIBRANDI-ROCHA, Marília. Writing by Ear: Clarice Lispector, Machado de Assis, Guimarães Rosa and the Mimesis of Improvisation. In: STANYEK, Jason; SANTOS, Alexandra. Brazilian Improvisations. Critical Studies in Improvisation. University of Guelph, Canada. v. 7, n. 1: 2011, 1-10. (on line http://www.criticalimprov.com/ article/view/1250).

LISPECTOR, Clarice. A hora da estrela. Rio de Janeiro: Editora Nova Fronteira, 1984.

MENARD, Andre. Edmond R. Smith's Writing Lesson: archive and representation in the $19^{\text {th }}$ Century Araucanía. In: DELMAS, Adrien; PENN, Nigel. Written culture in a colonial context: Africa and the Americas, 1500-1900. Cape Town: UCT Press, 2011. p. 56-69.

MUECKE, Stephen. Joe in the Andamans and other fictocritical stories. Sidney: LCP, 2008.

NANCY, Jean-Luc. À L'Écoute. Paris: Galilée, 2002.

ROSA, João Guimarães. Diálogo com Guimarães Rosa. Entrevista com Gunter Lorenz. In: COUTINHO, Eduardo. Fortuna Crítica. Rio de Janeiro: Civilização Brasileira, 1983, p.62-97. 
SAHLINS, Marshal. Culture and Practical Reason. Chicago: University of Chicago Press, 1976.

SOUZA, Marcela Coelho de; FAUSTO, Carlos. Reconquistando o campo perdido: o que Lévi-Strauss deve aos ameríndios. Rev. Antropol. [online]. 2004, v. 7, n. 1, p. 87-131.

STIERLE, Karlheinz. A Ficção. Trad. Luiz Costa Lima. NUÑEZ, Carlinda Fragale Pate; SANTOS, Francisco Venceslau dos. (Ed.). Rio de Janeiro: Caetés: Novos Cadernos de Mestrado UERJ, v. 1, 2006.

STRATHERN, Marilyn. No limite de uma certa Linguagem: Entrevista com Marilyn Strathern. Mana, 5(2): 1999. 157-175.

TAUSSIG, Michael. Mimesis and alterity: a particular history of the senses. New York: Routlege, 1993.

VIVEIROS DE CASTRO, Eduardo. O nativo relativo. Mana. v. 8, n. 1, 2002, p. $113-148$.

VIVEIROS DE CASTRO, Eduardo. O mármore e a murta. Sobre a insconstância da alma selvagem. A inconstância da alma selvagem e outros ensaios de antropologia. São Paulo: Cosac \& Naify. 2002b. p.183-264.

VIVEIROS DE CASTRO, Eduardo. Filiação intensiva e aliança demoníaca. Novos estudos. 77, v. 3, 2007, p. 91-126.

VIVEIROS DE CASTRO, Eduardo. The gift and the given: Three nano-essays on kinship and magic. BAMFORD, Sandra; LEACH, James (Ed.). Kinship and beyond: the genealogical model reconsidered. New York: Berghahn Books, 2009, p.237-268.

VIVEIROS DE CASTRO, Eduardo. "Transformação" na antropologia, transformação da "antropologia". Sopro, n. 58, Setembro 2011, http://www.culturaebarbarie.org/sopro/ n58pdf.html.

VIVEIROS DE CASTRO, Eduardo. Metafisicas Canibales: líneas de antropologia postestructural. [s.1.]: Katz Editores, 2011.

WAGNER, Roy. The invention of culture. Chicago: The University of Chicago Press, 1981.

WALKER, Michelle Boulous. Philosophy and the Maternal Body. London; New York: Routledge, 1998. 